\title{
DETERMINANT OF TAX PAYER COMPLIANCE IN KPP PRATAMA MAKASSAR UTARA
}

\author{
Anthony Holly, Maouren Angel Soewandi, Lukman Tuwo \\ Universitas Atma Jaya Makassar
}

\begin{abstract}
This research aims to determine (1) the influence of modernization tax administration system on taxpayer compliance in the KPP Pratama Makassar Utara, (2) the influence of tax knowledge on taxpayer compliance in the KPP Pratama Makassar Utara. The research data obtained from questionnaire were distributed to taxpayer in the KPP Pratama Makassar Utara. The sample determined by using purposive sampling with a sample size of 97 respondents. Further data have been obtained, tested by using multiple linear regression analysis. The results of hypothesis test prove that modernization tax administration system has positive impact on the taxpayer compliance and tax knowledge has positive impact on the taxpayer compliance.
\end{abstract}

Keywords: e-SPT, e-Faktur, tax knowledge, tax compliance.

\section{INTRODUCTION}

Tax as a source of state funding comes from community contributions aims to improve people's welfare through improvement and the addition of public services for equity and improvement community welfare can be achieved and reduce social inequality between residents. Definition of tax in Article 1 paragraph (1) of Law Number 28 Year 2007 concerning the Third Amendment to Law Number 6 of 1983 regarding General Provisions and Procedures for Taxation (KUP) is a mandatory contribution.

The level of taxpayer compliance in Indonesia is still relatively low. This can be seen from the failure to achieve the tax revenue target in 2017. The tax revenues from January to December 2017 only reached Rp 1.339,8 trillion (91 percent). This amount is still less than the target set by the government of $\mathrm{Rp}$

\footnotetext{
*Corresponding Author.

e-mail: shencuen90@gmail.com
} 
1.450,9 trillion. Unattainable tax revenue targets are caused by low taxpayer compliance (Julianto, 2018). The low level of taxpayer compliance makes tax payments stagnate (Rahayu, 2010).

The government makes various efforts to achieve the realization of tax revenues every year by changing the tax collection system from the official assessment system to the self-assessment system, namely the activity of calculating, calculating, collecting and reporting taxes fully in the hands of taxpayers (Resmi, 2009). Determination of the amount of taxpayer tax is the responsibility of the Fiscus in the official assessment system, so that all tax risks that arise will be the responsibility of the tax authorities, for example late paying or reporting due to delay in tax authorities stipulating the amount of taxpayer tax payable. This delay can be due to limited tax officers to calculate the amount of tax that must be paid by taxpayers, which is not small in number.

The government decides to change its tax collection system into a self-assessment system where the determination of the amount of tax that should be owed is the responsibility of the Taxpayer itself, so that all tax risks that arise are the responsibility of the Taxpayer itself. The Fiscal in the self-assessment system is only tasked with overseeing its implementation, by conducting an examination of the taxpayer's compliance with applicable tax laws and regulations. The self-assessment system that is now adopted by Indonesia provides great freedom and responsibility to taxpayers to carry out their tax obligations (Tarjo \& Kusumawati, 2008).

The Directorate General of Taxation (DGT) reformed the tax administration system called modernization in an effort to increase tax revenues. so that the potential for available tax revenues can be collected optimally. Modernization aims to achieve a high level of voluntary tax compliance, high levels of trust in tax administration and high taxation apparatus productivity. Tax modernization is carried out by prioritizing the provision of excellent service to taxpayers which is balanced with intensive supervision while implementing good governance in all work units within the DGT (Pandiangan, 2008).

The submission of electronic SPT (e-SPT) is an effort of the Directorate General of Taxes (DGT) as a form of improving the quality of tax services to taxpayers. Reporting of tax payable through manual SPT is considered to still have weaknesses, especially for taxpayers who conduct large enough transactions must attach large amounts of documents (hardcopy) to the Tax Service Office (KPP), while the 
process of recording data takes a long time so that SPT reporting becomes delayed and late and cause fines. In addition, errors can occur (human error) in the reprocessing of data recording manually by the tax authorities. e-SPT also provides ease of service so that taxpayers do not need to have many paper archives. As for the tax apparatus, e-SPT technology is able to facilitate them in managing the database due to document storage (Lingga, 2012).

The government also applies a new method so that all taxpayers are easy to administer and report Value Added Tax (VAT) to the local KPP according to their registered place, which is given the name e-faktur. The existence of this new efaktur is expected to make taxpayers obedient and aware in paying taxes, both individual taxpayers and corporate taxpayers. This is because e-faktur make it easy to administer tax invoices and VAT reporting.

Lack of tax knowledge by taxpayers can be an obstacle in implementing tax obligations. This problem can be overcome by conducting tax socialization. Taxation socialization is intended to provide knowledge to the community about the nature of taxes, the use of taxes and tax rules so that the public knows and carries out its tax obligations properly according to applicable regulations.

Based on the background of the research described above, the researchers formulating the problem of this study are:

1. Does the implementation of e-SPT have a positive and significant effect on Taxpayer compliance at KPP Pratama Makassar Utara?

2. Does the application of e-faktur have a positive and significant effect on Taxpayer compliance at KPP Pratama Makassar Utara?

3. Does knowledge of taxation have a positive and significant effect on taxpayer compliance at KPP Pratama Makassar Utara?

Khasanah (2013) in his research on the Influence of Tax Knowledge Modernization of Tax Administration System, and Taxpayer Awareness of Taxpayer Compliance at the Regional Office of the Directorate General of Taxes in Yogyakarta Special Region in 2013. The results showed that Together based on simultaneous tests of Taxation Knowledge, Modernization Tax Administration System, and Taxpayer Awareness have a positive and significant effect on Taxpayer Compliance. Handayani \& Supadmi (2013) in their study of the Effectiveness of the Effectiveness of VAT Period e-SPT on Corporate Taxpayer 
Compliance at West Denpasar KPP. The results of the study using simple linear regression techniques indicate that the effectiveness of the application of the VAT period e-SPT has a positive and significant effect on the compliance of Corporate Taxpayers in the West Denpasar Primary Tax Office.

Zuhdi et al. (2015) in his research on the Influence of the Application of eSPT and Knowledge of Taxation on the Compliance Level of Taxpayers in KPP Singosari. The results of this study indicate that the application of e-SPT and knowledge of taxation has an effect on taxpayer compliance which means, with the increasing application of e-SPT and knowledge of taxation will be able to increase taxpayer compliance.

Arif et al. (2016) in his research on the Effect of Knowledge About the Tax Administration System and Modernization of Taxation on the Compliance of Individual Taxpayers in KPP Pratama Singosari Malang. Based on the results of data analysis, all research variables significantly influence taxpayer compliance.

Kirana (2017) in his research on the Effect of the Application of e-SPT, Level of Understanding of Taxation, and Taxpayer's Awareness of Compliance with Corporate Taxpayers in reporting SPT at KPP Pratama Wates. The results of this study indicate that the adoption of e-SPT has a significant effect on the compliance of Corporate Taxpayers at Pratama Tax Office Wates.

\section{Compliance Theory}

Compliance theory was first put forward by Tyler (1990) which is a theory that describes a condition in which a person obeys orders or rules given. According to Tahar \& Rachman (2014) compliance with taxation is a responsibility to God, for the government and the people as taxpayers to fulfil all tax obligations and carry out their taxation rights. Taxpayer awareness is part of intrinsic motivation, namely motivation that comes from the individual itself and extrinsic motivation that comes from outside the individual, such as the push of the tax authorities to improve tax compliance.

\section{Taxpayer Compliance}

Taxpayer compliance can be defined as a situation where a taxpayer fulfils all tax obligations and applies his taxation rights (Rahman, 2010). According to 
Jotopurnomo \& Mangoting (2013), taxpayer compliance is a condition that arises in taxpayers in understanding all tax norms and trying to comply with all obligations of their obligations, starting from filling out tax forms completely and clearly, calculating the amount of tax owed correctly, and pay payable tax in a timely manner.

\section{Tax Administration System}

Tax reform in Indonesia has been carried out for the first time since 1983 from the official assessment system to the self-assessment system (Budileksmana, 2015). Self-assessment system is a modern taxation system that gives full trust to taxpayers to calculate, deposit and report on their tax obligations and efforts to encourage taxpayers to comply with tax obligations voluntarily (Choong \& Lai, 2009), while official assessment system is a collection system that authorizes the government to determine the amount of tax owed by taxpayers. This system change aims to reduce direct contact between tax officials and taxpayers who were previously feared to cause illegal practices to avoid or reduce tax obligations of the taxpayers concerned (Sari, 2013).

\section{Modernization of the Tax Administration System}

The modern tax administration system is the implementation of various programs and activities established in the medium-term tax administration reform. The implementation of this system is expected to be more efficient, economical and faster which is the embodiment of the medium-term tax administration reform programs and activities which are the priority of tax reforms that have been initiated by the Directorate General of Taxes since 2001 (Rahayu \& Lingga, 2009). According to Rahayu (2010), in early 2003 a team of mid-term tax administration modernization was formed which aimed to develop a modern tax administration with the following objectives:

a. Achievement of a high level of voluntary compliance of Taxpayers.

b. Achieving a high level of trust in administration and productivity of the taxation apparatus. 
e-SPT

Pandiangan (2008) states that what is meant by e-SPT is the submission of digital tax return to KPP electronically or by using computer media. According to Rahayu (2010) the notion of e-SPT is the submission of digital tax return to KPP electronically or by using computer media. DGT Regulation number 6/PJ/2009 article 1 concerning Procedures for Submitting Notification in electronic form is explained, e-SPT is taxpayer tax return data in electronic form made by taxpayers using the e-SPT application provided by the Directorate General of Taxes.

\section{e-Faktur}

e-faktur is a tax invoice made through an application or electronic system that is determined and/or provided and/or provided by the Directorate General of Taxes (Sakti \& Hidayat, 2015). The use of e-faktur is regulated in Minister of Finance Regulation Number 151/PMK.03/2013 concerning Procedures for Making and Procedure for Correction or Replacement of Tax Invoice. Based on these regulations, the Directorate General of Taxes issued a Director General of Taxes Regulation Number PER-16/PJ/2014 concerning Procedures for Making and Reporting on Electronic Tax Invoice (Lintang et al., 2017).

\section{Taxation Knowledge}

Rahayu (2010:29) states that the level of knowledge of community tax is adequate, it will be easy for taxpayers to comply with tax regulations. Prioritizing the interests of the state above personal interests will give people the sincerity to comply with their tax obligations. Sufficient knowledge obtained because of having a high level of education will certainly also be able to understand that by not fulfiling the regulation, they will receive sanctions in both administrative and fiscal criminal sanctions. Then it will be realized by a tax conscious society and willing to fulfil its tax obligations.

\section{Theoretical Framework}

Taxpayer compliance, implementation of e-SPT and e-Faktur can facilitate taxpayers in making tax returns and tax invoices. In addition to being supported 
by external factors such as the modernization of existing tax services, taxpayer compliance must also be supported by internal factors, namely taxation knowledge by the taxpayer himself, because if the taxpayer does not know how to perform his tax obligations properly, then the taxpayer it cannot fulfil its obligations in terms of paying and calculating its own taxes. These factors are a motivation for taxpayers who will increase taxpayer compliance. Based on the description above, the author describes the frame of mind as follows:

Independent Variable Dependent Variable

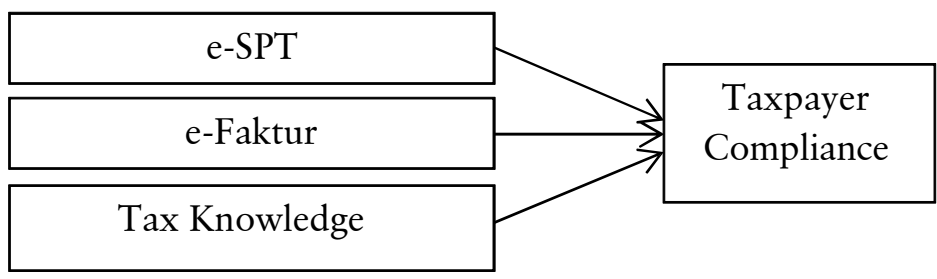

Figure 1 Theoretical Framework

\section{Development of Hypotheses}

\section{The Effect of e-SPT on Taxpayer Compliance}

The application of e-SPT will provide convenience for Taxpayers in making their SPT. The perceived ease of taxpayers will generate motivation and encourage awareness of taxpayers in carrying out their tax obligations. So the application of e-SPT by tax officials can be an extrinsic motivation that will increase taxpayer compliance with taxation obligations.

According to Zuhdi et al. (2015), reporting using e-SPT by taxpayers is intended to overcome the weaknesses of manual SPT. Some of the advantages of e-SPT are the first, which makes the taxation data used can be well organized, so as to facilitate the calculation of tax payable. The second advantage is the ease of making tax reports, making it more efficient in tax reporting. The results of Zuhdi et al. (2015) stated that the effect of implementing e-SPT has a significant effect on taxpayer compliance. The results of different studies were carried out by Sari et al. (2013), the application of e-SPT did not have a significant effect on taxpayer compliance in the KPP Pratama Makassar Utara. Based on these arguments, the authors develop the following hypothesis to be tested: 
H1: e-SPT has a positive and significant effect on tax compliance in KPP Pratama Makassar Utara.

\section{Effect of e-Faktur on Taxpayer Compliance}

Compliance Theory explains that the behavior of a Taxpayer is based on the Taxpayer's awareness of his tax obligations. Awareness itself is part of intrinsic motivation, namely motivation that comes from the individual itself, and extrinsic motivation that comes from outside the individual, such as the push of the tax apparatus to improve tax compliance. One of them is by improving service for taxpayers. This e-Faktur application will protect Taxpayers in misusing invalid tax invoices because each input and output tax invoice will go through an approval process from the Directorate General of Taxes. So, the application of e-faktur by the tax authorities becomes extrinsic motivation that increases taxpayer compliance in carrying out its tax obligations. According to Saragih (2017), e-Faktur is one of the improvements to the modern administration system for Taxpayers by the Director General of Taxes which serves to reduce misuse of tax invoices that are not in accordance with transactions, reduce multiple tax invoices, reduce the issuance of tax invoices for non authorized taxpayer, so as to increase compliance with Taxable Entrepreneurs.

The research conducted by Saragih (2017) states that the implementation of the e-Faktur system partially has a positive and significant effect on the compliance of Taxable Entrepreneurs. The results of a different study were conducted by Amelia (2016) which states that there is no significant influence between the application of e-invoices to the level of compliance of Taxable Entrepreneurs in KPP Medan. Based on these arguments, the authors develop the following hypothesis to be tested:

H2: e-Faktur has a positive and significant effect on taxpayer compliance at KPP Pratama Makassar Utara.

\section{Effect of Tax Knowledge on Taxpayer Compliance}

Taxpayer compliance is a behavior that is based on the awareness of a taxpayer on his tax obligations in the Compliance Theory. Awareness is part of intrinsic motivation. In the self- assessment system, where taxpayers must 
calculate, pay, and report their own taxes, of course this is in accordance with the compliance theory that requires intrinsic motivation, namely debriefing tax knowledge for taxpayers in order to carry out their tax obligations. Therefore, the level of knowledge of taxpayers on applicable tax regulations is expected to increase taxpayer compliance.

According to Kirana (2017) the level of understanding of taxation is the level of knowledge and thoughts of taxpayers on their tax obligations to contribute to the State in meeting national financing and development needs in order to achieve justice and prosperity. The results of Kirana's research (2017) state that the level of knowledge of taxation has a significant effect on taxpayer compliance. The results of different studies were carried out by Arifah et al. (2017) which showed that knowledge of taxation had no significant effect on individual taxpayer compliance at Demak Primary Tax Office. Based on these arguments, the authors develop the following hypothesis to be tested:

H3: Knowledge of taxation has a positive and significant effect on taxpayer compliance at KPP Pratama Makassar Utara.

\section{METHOD}

\section{Types of Research}

This research is an explanatory research conducted to examine the impact of tax modernization in the form of e-SPT and e-Faktur and tax knowledge on tax compliance.

\section{Population and Samples}

The population in this study were Taxable Entrepreneurs (PKP) registered at KPP Pratama Makassar Utara. The technique used in this research is Purposive Sampling technique. Determination of the sample uses the Slovin formula to get a number of PKP registered in KPP Pratama Makassar Utara as the following research objects:

$$
\mathrm{n}=\frac{\mathrm{N}}{\mathrm{Ne}^{2}+1}
$$




$$
\begin{gathered}
\mathrm{n}=\frac{3231}{3231(0,1)^{2}+1} \\
\mathrm{n}=96,99(97)
\end{gathered}
$$

Description:

$\mathrm{n}=$ Sum of sample

$\mathrm{N}=$ Sum of population

$\mathrm{e}=$ tolerable error limit $(10 \%)$

Based on data from KPP Pratama Makassar Utara, there were 3,231 registered Taxable Entrepreneurs. Then the number of samples taken in this study with a margin of error of $10 \%$ is: 97 respondents.

\section{Method of Collecting Data}

Data collection methods used in this study were questionnaires and interviews. To measure the opinions of respondents will be measured using a questionnaire with a Likert scale with the following pattern:

\begin{tabular}{ccccc}
\hline STS & TS & RR & S & SS \\
\hline 1 & 2 & 3 & 4 & 5 \\
\hline
\end{tabular}

Description:

STS : Strongly disagree

TS : Disagree

RR : Doubtful/don't know

$S$ : Agree

SS : Strongly agree

\section{Operational Definition of Variables Taxpayer Compliance}

Taxpayer compliance is the fulfilment of tax obligations carried out by taxpayers in order to contribute to development today which is expected to be provided voluntarily in its fulfilment. According to Rahayu (2010), tax compliance $(\mathrm{Y})$ can be identified from:

a. Compliance with taxpayers in registering themselves.

b. Compliance to deposit a Return Notification. 
c. Compliance in calculating, calculating and paying tax payable.

d. Compliance with reporting and payment of arrears.

\section{e-SPT}

The e-SPT application referred to as Electronic SPT is an application made by the Directorate General of Tax of the Ministry of Finance to be used by Taxpayers for convenience in submitting SPT. According to Lingga (2012), this e-SPT (X1) variable indicator is:
a. Practicality
b. Ease of data recording
c. Ease of use
d. Ease of calculation
e. Security
f. Ease of reporting

\section{e-Faktur}

Tax Invoice, hereinafter referred to as e-Faktur, is a Tax Invoice made through an application or electronic system determined and/or provided by the Directorate General of Taxes. According to Christin (2017), indicators of eFaktur (X2), as follows:
a. The purpose of the application of e-Invoice
b. Dissemination to taxable entrepreneur taxpayers
c. Constraints in the application of e-Invoice
d. Ease of input and output processes
e. Data is stored securely

\section{Taxation Knowledge}

Taxation Knowledge is information about taxation obtained through observation of one's mind. According to Rahayu (2010), indicators of tax knowledge (X3), as follows:
a. Knowledge of general provisions and tax procedures
b. Knowledge of taxation functions
c. Knowledge of the taxation system in Indonesia 


\section{Multiple Linear Regression Test}

The analytical method in this study uses multiple linear regression analysis. Multiple linear regression analysis is used to show the direction of the relationship between independent variables (the application of e-SPT, the application of e-Invoice, and knowledge of taxation) to the dependent variable (taxpayer compliance). The regression equation can be written as follows:

$$
\mathrm{Y}=\mathrm{a}+\mathrm{b} 1 \mathrm{X} 1+\mathrm{b} 2 \mathrm{X} 2+\mathrm{b} 3 \mathrm{X} 3+\mathrm{e}
$$

Description:

$\mathrm{Y}=$ Taxpayer compliance

$\mathrm{a}=$ Constant

b1, 2, 3, 4, 5 = Regression coefficient

$\mathrm{X} 1=\mathrm{e}-\mathrm{SPT}$ applied

$\mathrm{X} 2$ = e-Faktur applied

$\mathrm{X} 3=$ Tax knowledge

$\mathrm{e}=$ Error

\section{RESULTS}

\section{Descriptive Analysis}

This research was conducted by asking questions to taxpayers registered at KPP Pratama Makassar Utara using a questionnaire. The data collection procedure in this study was divided into 97 questionnaires. Data is carried out in December 2018-February 2019. Based on the research that has been done, the characteristics of the respondents can be identified as follows:

\section{Gender}

Based on Table 1 the results of processing primary data from 97 people who being the respondent in this study, it appears that most of them are men consisting of 52 people $(53,60 \%)$ and women consisting of 45 people $(46,39 \%)$.

Table 1 Frequency of Respondents by Gender

\begin{tabular}{ccc}
\hline Gender & Frequency & Percentage (\%) \\
\hline Male & 52 & 53.60 \\
Female & 45 & 46.40 \\
Total & 97 & 100 \\
\hline
\end{tabular}


Based on Table 2, the most respondents were around the age of 31-40 years as many as 42 people $(43,30 \%)$. There are 15 people aged between $20-30$ years $(15,47 \%), 41-50$ years there are 36 people $(37,11 \%)$, and ages between $51-60$ years there are as many as 4 people $(4,12 \%)$.

Table 2 Frequency of Respondents by Age

\begin{tabular}{ccc}
\hline Age & Frequency & Percentage (\%) \\
\hline $20-30$ & 15 & 15,47 \\
$31-40$ & 42 & 43,30 \\
$41-50$ & 36 & 37,11 \\
$51-60$ & 4 & 4,12 \\
Total & 97 & 100 \\
\hline
\end{tabular}

\section{Length of Taxpayer}

Based on Table 3 shows that the most respondents become taxpayers are $>$ 7 years as many as 37 people $(38,14 \%)$. Long as a taxpayer for $<1$ year there are 16 people (16,49\%), 1-3 years there are 19 people $(19,60 \%)$, and $3-7$ years there are 25 people $(25,77 \%)$.

Table 3 Frequency of Respondents by Length of Taxpayer

\begin{tabular}{ccc}
\hline Length & Frequency & Percentage $(\%)$ \\
\hline <1 year & 16 & 16,49 \\
1-3 year & 19 & 19,60 \\
3-7 year & 25 & 25,77 \\
> 7 year & 37 & 38,14 \\
Total & 97 & 100 \\
\hline
\end{tabular}

\section{Result of Descriptive Statistics Analysis}

Based on Table 4 it can be seen that the range of the minimum and maximum values of the e-SPT variable specified is $19-50$, with a mean value of 41,29 , and a standard deviation of 5,327. This illustrates that respondents tend to give agreed answers (answer score 4) to questionnaire question items, which means that most taxpayers consider e-SPT to be very important in the process of implementing tax rights and obligations. 
The minimum value range and the maximum value of the e-Faktur variable are $22-50$, with a mean value of 37,30 , and a standard deviation of 4,835 . This illustrates that respondents tend to give agreed answers (score answer 4) to the questionnaire question items given, which means that most taxpayers consider that e-Faktur is very important in an effort to improve tax compliance.

The range of minimum values and the maximum value of the taxpayer knowledge variable is $15-35$, with a mean value of 28,04 , and a standard deviation of 4,010. This illustrates that respondents tend to give agreed answers (score answer 4) to the questionnaire items given questions, which means that most taxpayers consider that knowledge of taxpayers is very important in an effort to improve taxpayer compliance.

The range of minimum values and the maximum value of the taxpayer compliance variable is $12-37$, with a mean value of 31,07 , and a standard deviation of 3,833 . This illustrates that respondents tend to give agreed answers (score answer 4) to the questionnaire question items given, which means most taxpayers carry out their duties in accordance with the system and predetermined tax rules.

Table 4 Results of Descriptive Statistics Analysis

\begin{tabular}{lccccc}
\hline & N & Minimum & Maximum & Mean & Std. Deviation \\
\hline e-SPT & 97 & 19 & 50 & 41,29 & 5,327 \\
e-Faktur & 97 & 22 & 50 & 37,30 & 4,835 \\
Tax knowledge & 97 & 15 & 35 & 28,04 & 4,010 \\
Tax Compliance & 97 & 12 & 37 & 31,07 & 3,833 \\
\hline
\end{tabular}

\section{Validity Test}

Based on the results of the validity test presented in Table 5, using Pearson's Correlation Product Moment as a tool to test validity (Ghozali, 2016), by correlating the scores of each statement item with the total score of the statement item with the instrument criteria declared valid if the probability value of $<0.05$ $(\alpha=5 \%)$ results are obtained, all the variables used in this study have a significant correlation range at the 0.01 level, thus indicating that the question items used in this study are valid, that is, it can measure each construct as expected. 
Table 5 Validity Test Results

\begin{tabular}{lccc}
\hline \multicolumn{1}{c}{ Variable } & Items & Correlation & Description \\
\hline$e$-SPT & 10 & $0,547^{* *}-0,640^{* *}$ & Valid \\
$e$-Faktur & 10 & $0.597^{* *}-0,628^{* *}$ & Valid \\
Tax knowledge & 7 & $0.547^{* *}-0,583^{* *}$ & Valid \\
Tax Compliance & 8 & $0,583^{* *}-0,640^{* *}$ & Valid \\
\hline
\end{tabular}

\section{Reliability Test}

Reliability testing in this study was carried out by Cronbach Alpha $(\alpha)$ statistical test. A construct or variable is said to be reliable if it gives the value of Cronbach Alpha>0.60 (Ghozali, 2016). Based on the reliability test results presented in Table 6, all the variables used in this study are reliable.

Table 6 Reliability Test Results

\begin{tabular}{lcc}
\hline \multicolumn{1}{c}{ Variable } & Cronbach's Alpha & Description \\
\hline e-SPT & 0.814 & Reliable \\
e-Faktur & 0.799 & Reliable \\
Tax knowledge & 0.824 & Reliable \\
Tax Compliance & 0.803 & Reliable \\
\hline
\end{tabular}

\section{Classic Assumption Test Normality Test}

Based on the results of normality using Kolmogorov Smirnov presented in Table 7 , all variables used in this study have a significant value of $0.065>0.05$, thus indicating that the data used in this study are normally distributed.

Table 7 Normality Test Results

\begin{tabular}{lc}
\hline \multicolumn{2}{c}{ One-Sample Kolmogorov-Smirnov Test } \\
\hline & Unstandardized Residual \\
\hline Kolmogorov-Smirnov Test & 0,087 \\
Asymp. Sig. (2-tailed) & 0,065 \\
\hline
\end{tabular}




\section{Multicollinearity Test}

Based on the results of the multicollinearity test presented in Table 8 the eSPT variable (X1) has a Tolerance value of 0,573 with a VIF value of 1,746 , the e-Faktur variable (X2) has a Tolerance value of 0,526 with a VIF value of 1,901, and a taxpayer knowledge variable (X3) has a Tolerance value of 0,592 with a VIF value of 1,690. From the data above can be concluded that there is no multicollinearity between independent variables.

Table 8 Multicollinearity Test Results

\begin{tabular}{|c|c|c|c|c|}
\hline \multirow{2}{*}{ Variabel } & \multirow{2}{*}{$\begin{array}{c}\text { Variable } \\
\text { Endogenous }\end{array}$} & \multicolumn{2}{|c|}{ Collinearity Statistics } & \multirow{2}{*}{ Description } \\
\hline & & Tolerance & VIF & \\
\hline E-SPT & \multirow{3}{*}{$\begin{array}{l}\text { Taxpayer } \\
\text { Compliance }\end{array}$} & 0.573 & 1.746 & $\begin{array}{l}\text { There is no } \\
\text { multicollinearity }\end{array}$ \\
\hline E-Faktur & & 0.526 & 1.901 & $\begin{array}{l}\text { There is no } \\
\text { multicollinearity }\end{array}$ \\
\hline Tax Knowledge & & 0.592 & 1.690 & $\begin{array}{l}\text { There is no } \\
\text { multicollinearity }\end{array}$ \\
\hline
\end{tabular}

\section{Heteroscedasticity Test}

Based on the heteroscedasticity test results presented in Table 9, it can be seen that the sig value in the e-SPT variable is 0,223 , the e-Faktur variable is 0,891 , and the tax knowledge variable which is 0,56 is greater than 0,05 , it can be concluded that each variable does not occur heteroscedasticity.

Table 9 Heteroscedasticity Test Results

\begin{tabular}{llcl}
\hline \multicolumn{1}{c}{ Variable } & $\begin{array}{c}\text { Variable } \\
\text { Endogenos }\end{array}$ & Sig & Description \\
\hline E-SPT & Taxpayer & 0,223 & There is no heteroscedasticity \\
E-Faktur & Compliance & 0,891 & There is no heteroscedasticity \\
Tax Knowledge & & 0,056 & There is no heteroscedasticity \\
\hline
\end{tabular}

\section{Hypothesis Testing}

\section{Determination Coefficient Test $\left(\mathbf{R}^{2}\right)$}

Based on Table 10, the Adjusted R Square value is 0,514 or $51,4 \%$, which means that the taxpayer compliance variable can be explained by the variables e- 
SPT, e-Faktur, and tax knowledge of 51,4\% and the remaining 48,6\% (100\%$51,4 \%)$ explained by other factors not included in this study.

Table 10 Determination Coefficient Test Results $\left(\mathbf{R}^{2}\right)$

\begin{tabular}{ccccc}
\hline Model & R & R Square & $\begin{array}{c}\text { Adjusted R } \\
\text { Square }\end{array}$ & $\begin{array}{c}\text { Std. Error of } \\
\text { the Estimate }\end{array}$ \\
\hline 1 & 0,727 & 0,529 & 0,514 & 2,673 \\
\hline
\end{tabular}

\section{Effect of e-SPT on Taxpayer Compliance}

Based on the results of statistical tests in Table 11, the e-SPT variable has a significance of 0,000 or less than 0,05 . This states that the independent variable has a positive and significant influence on the dependent variable, so H1 is accepted.

Table 11 Test Results $\mathbf{t}$

\begin{tabular}{|c|c|c|c|c|c|c|c|}
\hline & \multirow[t]{2}{*}{ Model } & \multicolumn{2}{|c|}{$\begin{array}{l}\text { Unstandardized } \\
\text { Coefficients }\end{array}$} & \multirow{2}{*}{$\begin{array}{c}\text { Standardized } \\
\text { Coefficients } \\
\text { Beta } \\
\end{array}$} & \multirow[t]{2}{*}{ t } & \multirow{2}{*}{ Sig. } & \multirow[t]{2}{*}{ Note } \\
\hline & & B & Std. Error & & & & \\
\hline \multirow{4}{*}{1} & (Constant) & 6.463 & 2.425 & & 2.665 & .009 & \\
\hline & e-SPT & .246 & .068 & .342 & 3.638 & .000 & Significant \\
\hline & e-Faktur & .223 & .078 & .281 & 2.868 & .005 & Significant \\
\hline & Tax Knowledge & .218 & .088 & .228 & 2.467 & .015 & Significant \\
\hline
\end{tabular}

\section{Effect of e-Faktur on Taxpayer Compliance}

Based on the results of statistical tests in Table 11, the e-Invoice variable has a significance of 0.005 or less than 0.05 . This states that the independent variable has a positive and significant influence on the dependent variable, so $\mathrm{H} 2$ is accepted.

\section{Effect of Tax Knowledge on Taxpayer Compliance}

Based on the results of statistical tests in Table 11, the e-Invoice variable has a significance of 0.015 or less than 0.05 . This states that the independent variable has a positive and significant influence on the dependent variable, so that $\mathrm{H} 3$ is. 


\section{Simultaneous Significance Test (F Test)}

The test results of $\mathrm{F}$ Table 12 show that all independent variables namely eSPT, e-Faktur, and knowledge of taxation have an effect simultaneously on taxpayer compliance with the value of sig. equal to 0,000 below the alpha value of 0,05 . Thus, it can be concluded that the variables and models built from the Compliance Theory framework are appropriate.

Table 12 Simultaneous Significance Test Results (Test F)

\begin{tabular}{llccccc}
\hline & Model & Sum of Squares & df & Mean Square & F & Sig. \\
\hline & Regression & 745.824 & 3 & 248.608 & 34.785 & $.000^{\mathrm{b}}$ \\
1 & Residual & 664.671 & 93 & 7.147 & & \\
Total & 1.410 .495 & 96 & & & \\
\hline
\end{tabular}

\section{Multiple Linear Regression Test}

Multiple linear regression test presented on Table 13 below:

Table 13 Results of Multiple Linear Regression Calculation

\begin{tabular}{llccc}
\hline \multicolumn{1}{c}{ Variable Exogenous } & $\begin{array}{c}\text { Variable } \\
\text { Endogenous }\end{array}$ & $\begin{array}{c}\text { Unstandardized Beta } \\
\text { Coefficient }\end{array}$ & Sig. & Desc \\
\hline$e$-SPT (X1) & Taxpayer & 0,246 & 0,000 & Significant \\
$e$-Faktur (X2) & Compliance (Y) & 0,223 & 0,005 & Significant \\
Tax knowledge (X3) & & 0,218 & 0,015 & Significant \\
\hline
\end{tabular}

Based on calculation on Table 13 the regression equation can be shown below:

$$
\mathrm{Y}=6,463+0,246 \mathrm{X} 1+0,223 \mathrm{X} 2+0,218 \mathrm{X} 3+0,697
$$

The results of the regression equation above explain that:

1. A constant of 6.463 which states that if the independent variables (e-SPT, eInvoice, knowledge of taxation) do not exist, then there is still taxpayer compliance at KPP Pratama Makassar Utara.

2. Effect of e-SPT on taxpayer compliance

The e-SPT variable has an unstandardized beta coefficient for taxpayer compliance of 0,246 with a sig value. 0,000 , which means that e-SPT has a 
positive influence on taxpayer compliance or with increasing e-SPT will increase taxpayer compliance. Statistically the influence is quite strong with the magnitude of the effect of the variable e-SPT on tax compliance at KPP Pratama Makassar Utara.

3. Effect of e-Faktur on taxpayer compliance

The e-Faktur variable has an unstandardized beta coefficient value for taxpayer compliance of 0,223 with a sig value. 0,005 , which means that e-Faktur has a positive influence on taxpayer compliance or with increasing e-Faktur will increase taxpayer compliance. Statistically the influence is quite strong with the magnitude of the effect of the e-Invoice variable on taxpayer compliance at KPP Pratama Makassar Utara.

4. Effect of tax knowledge on taxpayer compliance

The variable knowledge of taxation has a beta unstandardized coefficient for taxpayer compliance of 0,218 with the value of sig. 0,015 , which means that knowledge of taxation has a positive influence on taxpayer compliance or with increasing knowledge of taxation will increase taxpayer compliance. Statistically the influence is quite strong with the magnitude of the influence of knowledge taxation variable on tax compliance at KPP Pratama Makassar Utara.

\section{DISCUSSION}

\section{Effect of e-SPT on Taxpayer Compliance}

The application of e-SPT in the taxation system in Indonesia which adheres to the self- assessment system requires taxpayers to carry out their own tax obligations, namely to calculate, deposit and report. SPT reporting using the eSPT application is considered more efficient than using manual SPT because in the implementation of e-SPT, taxpayers can meet fast and accurate data requirements from the tax authorities in reporting using a computer system. In addition, the use of e-SPT as a means of reporting tax obligations provides convenience in the availability of places where the presence of e-SPT documentation can be done electronically and does not take place. e-SPT reporting using a computer system can also minimize the human error in the calculation and recording of data, this is because a computer system can automatically carry out calculation commands quickly and accurately. 
The results of this study are also in line with the Compliance Theory. Taxpayer compliance is a behaviour based on the awareness of a taxpayer on his tax obligations while remaining based on established legislation. The ease in carrying out tax obligations of taxpayers will generate motivation and encourage awareness of taxpayers in carrying out their tax obligations. The implementation of e-SPT by taxpayers can be an extrinsic motivation that will increase taxpayer compliance with taxation obligations.

This research is in line and consistent with previous research by Zuhdi et al. (2015) which states that the effect of implementing e-SPT has a significant effect on taxpayer compliance. Some of the advantages of e-SPT are first, which makes the tax data used can be well organized, making it easier calculation of tax payable. The second advantage is the ease of making tax reports, making it more efficient in tax reporting.

The results of this study also support the research by Kirana (2017) which states that the implementation of e-SPT has a significant effect on compliance of Corporate Taxpayers at KPP Pratama Wates. The government provides e-SPT applications so that it can be used by taxpayers to fill and report tax returns (SPT) easily, quickly and accurately in order to increase the motivation of taxpayers in carrying out their obligations in tax reporting.

\section{Effect of e-Faktur on Taxpayer Compliance}

e-Faktur make it easy for taxpayers to make invoices and storing it electronically. The application of e-Faktur also provides security because each tax invoice will go through an approval process from the Directorate General of Tax in the form of a $\mathrm{QR}$ code so that Taxpayers are protected from fictitious tax invoices from the opponent of the transaction. In e- Invoice Reporting Taxpayers can also use the QR code scanner to be sure that the VAT paid is actually deposited to the state.

Taxpayer compliance in the Compliance Theory explains that the behaviour of a Taxpayer is based on the Taxpayer's awareness of his tax obligations. Awareness itself is part of intrinsic motivation, namely motivation that comes from the individual itself, and extrinsic motivation that comes from outside the individual, such as the push of the tax apparatus to improve tax compliance. One of them is by improving service for taxpayers. 
This research is consistent and in line with previous research by Saragih (2017) stating that the application of e-Faktur system has a positive and significant effect on the compliance of Taxable Entrepreneurs. The application of e-Faktur reporting has several advantages that are used as indicators on variables, namely, wet signatures are replaced with digital signatures, e-Faktur does not have to be printed so that it reduces costs paper, printing costs, and storage costs, get the convenience of being able to request the Tax Invoice serial number through the Directorate General of Tax website so there is no need to come to the Tax Service Office (KPP) so that it will increase tax compliance

The results of this study were also supported by Husnurrosyidah \& Suhadi (2017) who stated that the application of the e-Faktur system had a positive and significant effect on tax compliance. The implementation of the e-Faktur system has a significant but not dominant influence on taxpayer compliance because the implementation of the e-Faktur system is one of several efforts made by the Directorate General of Taxes to improve taxpayer compliance. The existence of e-invoices in addition to providing convenience for taxpayers, e-Faktur can also minimize the use of fictitious tax invoices.

\section{Effect of Tax Knowledge on Taxpayer Compliance}

Tax Knowledge is tax information that can be used by taxpayers to take certain directions and strategies by implementing their rights and obligations in the taxation field, as well as thoughts from a taxpayer through training efforts (Hidayatulloh, 2010). The higher the knowledge and understanding of taxpayers, the taxpayer can follow the rules in accordance with the tax provisions. But if the taxpayer does not have knowledge about tax regulations, then the taxpayer cannot follow the rules regarding taxes. Socialization from DGT can improve the knowledge of taxpayer about the new rule and techniques in taxation.

The results of this study are in line with the theory of compliance. Taxpayer compliance is a behaviour based on the awareness of a taxpayer on his tax obligations. Awareness itself is part of intrinsic motivation that comes from the individual itself, namely the provision of tax knowledge by taxpayers in order to carry out their tax obligations properly. Therefore, the level of taxpayer's knowledge of the applicable tax regulations will increase Taxpayer Compliance. 
This research is consistent and in line with previous research by Khasanah (2013) which states that Tax Knowledge has a positive and significant effect on Taxpayer Compliance. Tax knowledge is used by taxpayers as tax information in carrying out tax actions such as calculating, calculating, paying, and reporting the amount of tax paid. And it will also have an impact on tax revenues received by the state if the people already have high taxation knowledge. The results of this study are also supported by Kirana (2017) which states that the level of understanding of taxation has a positive and significant effect on taxpayer compliance. If the Taxpayer has a high level of understanding regarding the procedures for taxation, obligations and rights, then this will form a positive attitude from the Taxpayer, on the contrary if the Taxpayer has a low level of understanding of taxation regarding tax procedures, obligations and rights, this will form a negative attitude which will further reduce taxpayer compliance.

\section{REFERENCES}

Amelia, R. (2016). Pengaruh Penerapan e-Faktur dan e-SPT PPN Terhadap Tingkat Kepatuhan Wajib Pajak. Medan: Universitas Sumatra Utara.

Arif, A., S. H., \& Hidayat, R. (2016). Pengaruh Pengetahuan Tentang Sistem Administrasi Perpajakan dan Modernisasi Administrasi Perpajakan Terhadap Kepatuhan Wajib Pajak Orang Pribadi. Jurnal Mahasiswa Perpajakan, X.

Arifah, Andini, R., \& Raharjo, K. (2017). Pengaruh Modernisasi Sistem Administrasi Perpajakan, Kualitas Pelayanan, Pengetahuan Perpajakan, Sanksi Perpajakan dan Kesadaran Perpajakan terhadap Kepatuhan Wajib Pajak Orang Pribadi pada Kantor Pelayanan Pajak Demak selama Periode (2012-2016). Universitas Pandanaran, 14.

Budileksmana, A. (2015). Manfaat dan Peranan Pajak dalam Era Self Assessment Perpajakan. Jurnal Akuntansi dan Investasi.

Choong, K. F. \& Lai, M. L. (2009). Self Assessment Tax System and Compliance Complexities: Tax Practitioners' Perspectives. Oxford Business \& Economics Conference Program.

Christin, L. (2017). Pengaruh Penerapan e-Faktur dan e-SPT PPN terhadap Kepatuhan Perpajakan Pengusaha Kena Pajak dengan Kemampuan Menggunakan Internet sebagai Variabel Moderating. Media Akuntansi Perpajakan, 2(1), 35-44. 
Ghozali, I. (2016). Aplikasi Analisis Multivariate dengan Program IBM SPSS 23, Cetakan ke-VIII (8th ed.). Semarang: Badan Penerbit Universitas Diponegoro. Handayani, K. P. \& Supadmi, N. L. (2013). Pengaruh Efektivitas e-SPT masa PPN pada Kepatuhan Wajib Pajak Badan di KPP Pratama Denpasar Barat. e-Jurnal Akuntansi Universitas Udayana, 19-38.

Hidayatulloh. (2010). Pengaruh Pelayanan Pajak dan Pengetahuan Pajak terhadap Kepatuhan Wajib Pajak (pada KPP Bandung). Universitas Komputer Indonesia.

Husnurrosyidah \& Suhadi. (2017). Pengaruh e-Filing, e-Billing, dan e-Faktur terhadap Kepatuhan Pajak pada BMT se-Kabupaten Kudus. Jurnal Analisa Akuntansi dan Perpajakan STAIN Kudus, 1(1), 97-106.

Ilyas, W. B. \& Burton, R. (2007). Hukum Pajak. Jakarta: Salemba Empat.

Jotopurnomo, C. \& Mangoting, Y. (2013). Pengaruh Kesadaran Wajib Pajak, Kualitas Pelayanan Fiskus, Sanksi Perpajakan, Lingkungan Wajib Pajak Berada terhadap Kepatuhan Wajib Pajak Orang Pribadi di Surabaya . Tax and Accounting Review, 49-53.

Julianto, P.A. "Penerimaan Perpajakan 2017 Capai Rp 1.339 Triliun” Kompas.com, diakses tanggal 13 November 2018. https://ekonomi.kompas.com/read/2018/ 01/02/184405726/penerimaanperpajakan-2017-capai-rp-1339-triliun.

Khasanah, S. N. (2013). Pengaruh Pengetahuan Perpajakan, Modernisasi Sistem Administrasi Perpajakan, dan Kesadaran Wajib Pajak terhadap Kepatuhan Wajib Pajak pada Kantor Wilayah Direktorat Jenderal Pajak Daerah Istimewa Yogyakarta. Jurnal Profita, 8.

Kirana, L. A. (2017). Pengaruh Penerapan e-SPT, Tingkat Pemahaman Perpajakan, dan Kesadaran Wajib Pajak terhadap Kepatuhan Wajib Pajak Badan dalam Melaporkan SPT (di KPP Pratama Wates). Yogyakarta: Universitas PGRI Yogyakarta.

Lingga, I. S. (2012). Pengaruh Penerapan e-SPT PPN terhadap Efisiensi Pengisian SPT Menurut Persepsi Wajib Pajak: Survei terhadap Pengusaha Kena Pajak pada KPP Pratama "X". Jurnal Akuntansi, 4.

Lintang, K., Kalangi, L., \& Pusung, R. (2017). Analisis Penerapan e-Faktur Pajak dalam Upaya Meningkatkan Kepatuhan Pengusaha Kena Pajak untuk Pelaporan SPT Masa PPN pada KPP Pratama Manado. Jurnal Riset Ekonomi, Manajemen, Bisnis dan Akuntansi, 5(2). 
Pandiangan, L. (2008). Modernisasi dan Reformasi Pelayanan Perpajakan. Jakarta: Elex Media Komputindo.

Rahayu, S. K. (2010). Perpajakan Indonesia: Konsep dan Aspek Formal. Yogyakarta: Graha Ilmu.

Rahayu, S. \& Lingga, I. S. (2009). Pengaruh Modernisasi Sistem Administrasi Perpajakan Terhadap Kepatuhan Wajib Pajak. Jurnal Akuntansi, 1(2), 119138.

Rahman, A. (2010). Paduan Pelaksanaan Administrasi Perpajakan. Bandung: Penerbit Nuansa.

Resmi, S. (2009). Perpajakan: Teori dan Kasus, Edisi ke-5. Yogyakarta: Salemba Empat.

Sakti, N. W. \& Hidayat, A. (2015). e-Faktur: Mudah dan Cepat. Jakarta: Visimedia. Saragih, H. (2017). Pengaruh Penegasan Penerapan Pelaporan Faktur Menggunakan e-Faktur Terhadap Kepatuhan Pengusaha Kena Pajak dalam Memenuhi Kewajiban Pelaporan PPN.

Sari, D. (2013). Konsep Dasar Perpajakan. Bandung: PT. Refika Aditama.

Sari, N. A., Bandang, A., \& Rura, Y. (2013). Analisis Tingkat Kepatuhan Wajib Pajak atas Penyampaian SPT Masa PPN dengan Penerapan Electronik (e-SPT) di Kantor Pelayanan Pajak Makassar. Makassar: Hasanuddin University.

Sofiyana, Suci, Hamid, Djamhur, \& Riza, M. F. (2014). Pengaruh Modernisasi Sistem Administrasi Perpajakan terhadap Tingkat Kepatuhan Wajib Pajak pada Kantor Pelayanan Pajak Pratama Batu. Jurnal Mahasiswa Perpajakan, 3(1).

Tahar, A. \& Rachman, A. K. (2014). Pengaruh Faktor Internal dan Faktor Eksternal terhadap Kepatuhan Wajib Pajak. Jurnal Akuntansi dan Investasi, 57-67.

Tarjo, \& Kusumawati, I. (2008). Analisis Perilaku Wajib Pajak Orang Pribadi terhadap Pelaksanaan Self Assessment System. Jurnal Akuntansi.

Tyler, T. R. (1990). Why People Obey the Law. New Heaven and London: Yale University Press.

Undang-Undang Republik Indonesia Nomor 28 Tahun 2007 tentang Perubahan Ketiga atas Undang-Undang Nomor 6 Tahun 1983 tentang Ketentuan Umum dan Tata Cara Perpajakan (KUP).

Zuhdi, F. A., Topowijono, \& Azizah, D. F. (2015). Pengaruh Penerapan e-SPT dan Pengetahuan Perpajakan terhadap Kepatuhan Wajib Pajak. Jurnal Mahasiswa Perpajakan, 7. 